DOI: $10.32702 / 2307-2156-2020.1 .3$

УДК 628.5:669

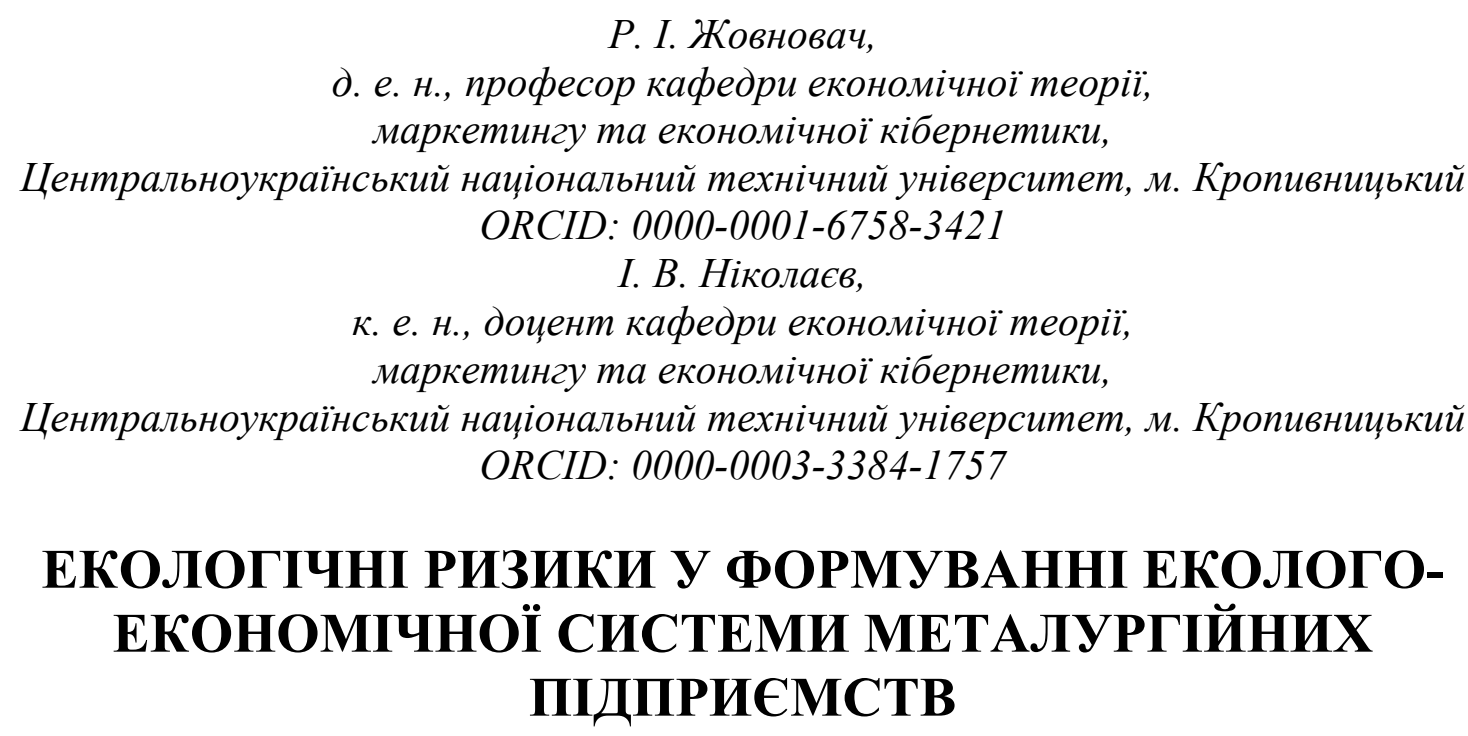

R. Zhovnovach

Doctor of Economic Sciences, Professor of economic theory, marketing and economic cybernetics of the department I. Nikolaev

PhD in Economics, Associate Professor of economic theory, marketing and economic cybernetics of the department, Central Ukrainian National Technical University, Kropyvnytskyi

\title{
ENVIRONMENTAL RISKS IN THE FORMATION OF ECOLOGICAL AND ECONOMIC SYSTEM OF METALLURGICAL ENTERPRISES
}

Статтю присвячено проблемі економічної очінки та управління екологічними ризиками в контексті формування еколого-економічної системи металургійних підприємств. Досліджено негативний вплив металургійних підприємств на навколишнє природне середовище регіонів та держави в иілому. Встановлено залежність ступеня забруднення навколишнього середовища від викидів шкідливих речовин в атмосферне повітря, скидів забруднених стічних вод, забруднення грунтів та накопичення небезпечних твердих відходів діяльності металургійних підприємств. Обтрунтовано необхідність формування нової синергетичної системи, здатної до адаптації, самоорганізачії та розвитку у вигляді еколого-економічної системи, яку спрямовано на мінімізаџію ризиків забруднення навколишнього природного середовища та зменшення економічних збитків суб'єктів господарської діяльності. Надано рекомендації з формування еколого-економічної системи металургійних підприємств з метою підвищення екологічної дієвості, забезпечення економічно ефективного функиіонування та розвитку. Доведено пріоритетність вивчення та оцінки екологічних ризиків, визначення їх економічної вартості, а також обгрунтування екологічних заходів з управління еколого-економічною діяльністю підприємства. Розглянуто порядок економічної оцінки екологічних ризиків, який грунтується на кількісних розрахунках 
за розробленими напрямами оцінювання. Запропоновано принципову схему формування системи управління екологічними ризиками підприємств металургійної промисловості як окремого специфічного об'єкту управління

The article is devoted to the problem of environmental risks economic assessment and their management in the context of the formation of ecological and economic system of metallurgical enterprises. Metallurgical enterprises are among the most important sources of environmental threats has been established. The negative impact of metallurgical enterprises on the environment of the regions in which they produce, and the country as a whole, was studied. The dependence of the degree of environmental pollution on the emissions of harmful substances into the atmospheric air, discharges of polluted wastewater, soil contamination and accumulation of hazardous solid wastes from the activity of metallurgical enterprises has been established. One of the main directions of environmental policy of metallurgical enterprises is the strengthening of its economic component, the application of economic instruments to improve environmental conditions. The necessity of forming a new synergistic system capable of adaptation, self-organization and development, such as ecological and economic system, aimed at minimizing the risks of environmental pollution and at reducing economic losses of economic entities is substantiated. Analyzed different interpretations of ecological and economic system. Recommendations have been given on the formation of the ecological and economic system of metallurgical enterprises in order to increase their ecological efficiency and to ensure economically efficient functioning and development of metallurgical enterprises. The basic aspects that contribute to solving a number of environmental issues and sustainable development. The priority of study and assessment of ecological risks, determination of their economic value, as well as substantiation of ecological measures for management of ecological and economic activity of an enterprise were proved. The procedure of economic assessment of environmental risks, which is based on quantitative calculations by the developed directions of assessment, is considered. The basic scheme of the formation of ecological risks management system of metallurgical enterprises as a separate specific management object has been proposed

Ключові слова: екологічний ризик, еколого-економічна система, оиінка ризиків, управління ризиками, сталий розвиток, металургійне підприємство

Keywords: ecological risk, ecological and economic system, risk assessment, risk management, sustainable development, metallurgical enterprise

Сучасний розвиток України та іiі металургійних підприємств зокрема відбувається під впливом глобальних та національних трансформаційних змін. 3 одного боку, глобалізаційні та євроінтеграційні процеси супроводжуються зростанням взаємозалежності національних економік, їх взаємопроникнення, що дозволяє забезпечити прискорення науково-технічного прогресу, підвищення інноваційної активності та соціальноекономічного зростання, а 3 іншого - національна економіка характеризується напруженістю економічних відносин, посилиленням розбалансованості усіх виробничих, комерційних та інвестиційних процесів. В той же час, функціонування гірничо-металургійного комплексу України базується на застарілих виробничих потужностях, які характеризуються техніко-технологічною відсталістю, високою енерго- і ресурсомісткістю виробництва та екологічним навантаженням, що у поєднанні з вичерпанням природних ресурсів, труднощами їхнього відновлення, погіршує якість навколишнього середовища та стає джерелом економічних втрат металургійних підприємств, регіонів та держави в цілому.

Результатами неефективного еколого-економічного управління металургійних підприємств стає надмірне екологічне навантаження на суспільство та значні фінансові витрати, які спрямовуються на боротьбу 3 накопиченими наслідками погіршення стану навколишнього середовища у порівнянні 3 витратами на забезпечення екологічної безпеки. За таких обставин, створення передумов сталого економічного розвитку металургійних підприємств потребує концептуально нових підходів до формування ефективної екологоекономічної системи, управління екологічними ризиками та мінімізації цього впливу на господарську діяльність.

Аналіз останніх досліджень і публікацій. Проблематика формування еколого-економічної системи, оцінки екологічних ризиків та здійснення еколого-економічного управління в контексті економічного розвитку 
підприємств перебуває у центрі уваги як українських, так і закордонних науковців. Зокрема, дослідженнями взаємозв'язків економіки та природного середовища займалося чимало вітчизняних науковців: І. Дегтярова, О. Мельник, М. Лемешев, М. Мелешкіна, Н. Мойсеєва, Л. Розанова та інші. Вивченню сутності екологоекономічних систем (ЕЕС), їхньої структури та системоутворюючих чинників присвячено дослідення Ю. Бурих, С. Марова, I. Грабинського, Л. Загвойської, H. Daly, R. Costanza, О. Каленської, О. Кузьменко, К. Mäler, M. Моiсєєва, Р. Розум та ін. Проблематика оцінки та управління екологічними ризиками отримала розвиток у роботах таких науковців як В. Вітлінський, О. Веклич, Л. Главинська, А. Слохін, С. Ілляшенко, В. Кислий, А. Качинський, А. Куклін, С. Іванюта, І. Стародубцев, К. Таранюк, А. Татаркін, А. Черепанова та інші. Екологічним аспектам функціонування підприємств металургійної галузі в цілому присвячені праці М. Бесєди, О. Білецької, Б. Данилишина, Н. Каменевої, О. Криворучкіної, В. Міщенко, В. Никоненка, М. Онула, О. Паламарчука, В. Фещенка.

Водночас, дослідження еколого-економічного управління, переважно зорієнтовані на зниження економічних витрат та негативного впливу на навколишнє середовище, носять фрагментарний характер. У вітчизняній економічній літературі не сформовано єдиного підходу до формування ефективної ЕЕС компаній та економічної оцінки екологічного ризику металургійних підприємств.

Метою статті $є$ розвиток концептуальних засад оцінки та управління екологічним ризиком в контексті створення еколого-економічної системи металургійних підприємств.

Виклад основного матеріалу. Економічний розвиток України значною мірою залежить від функціонування гірничо-металургійного комплексу, який сприяє вирішенню багатьох важливих народногосподарських проблем. Фактично, підприємства металургійної галузі виконують містоутворювальний характер, створюючи соціальну інфраструктуру регіону, формуючи місцеві бюджетів та забезпечуючи робочими місцями переважну частину населення.

Водночас, діяльність металургійних підприємств стає причиною погіршення екологічної ситуації в регіонах їх функціонування. Діяльність металургійних підприємств призводить до виникнення ряду екологічних проблем:

- забруднення атмосфери;

- забруднення водних ресурсів;

- утворення та накопичення промислових відходів;

- порушення ландшафту, погіршення стану грунтів, нанесення шкоди рослинному і тваринному світу;

- виникнення техногенних зон і геохімічних аномалій;

- пагубний вплив на здоров'я людини.

Безпосередніми об’єктами негативного впливу металургійних підприємств на забруднення навколишнього середовища $\epsilon$ атмосфера, стічні води та грунт. Високий рівень забруднення спостерігається поблизу великих промислових агломерацій, зокрема, пов'язаних із видобутком металургійної сировини таких як наприклад, Нікополь-Марганець-Орджонікідзевський басейн, Жовтоводсько-П'ятихатсько-Вільногірська агломерація, внаслідок чого має місце перевищення гранично припустимих концентрацій (ГПК) небезпечних речовин.

Так, за індексом забруднення атмосфери (IЗА), який враховує ступінь забруднення атмосферного повітря по п'ятьма пріоритетними забруднювальними домішками, дуже високий рівень забруднення у 2018 році спостерігався у Маріуполі та Дніпрі, високий - у Одесі, Кам’янському, Києві, Кривому Розі, Луцьку, Миколаєві, Слов’янську, Краматорську, Рубіжному, Львові, Запоріжжі, Лисичанську, Херсоні, Кременчуці (рис. 1). Зазначимо, що із шістнадцяти наведених міст, сім мають потужні металургійні підприємства (Маріуполь, Дніпро, Кам’янське, Кривий Ріг, Миколаїв, Краматорськ, Запоріжжя). 


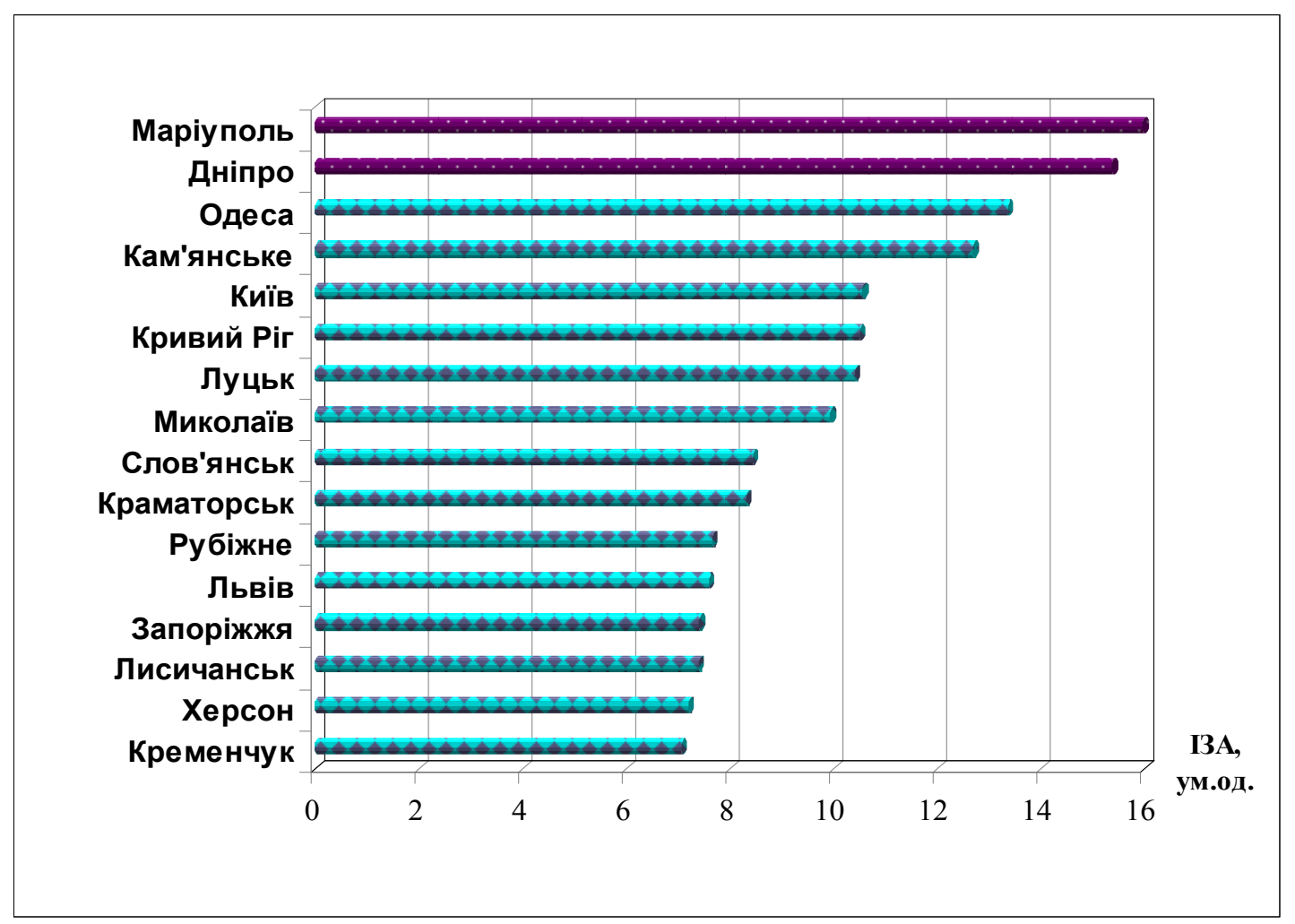

Рис.1. Значення ІЗА в найбільш забруднених містах України у 2018 році Джерело [15]

За даними літературних джерел $[1,24,26]$ негативний вплив забруднення навколишнього середовища підприємств металургійної галузі за результатами їх діяльності спричиняють такі види виробництв:

- коксохімічне характеризується викидами в атмосферне повітря оксидів та діоксину вуглецю, оксидів сірки. Охолодження коксу супроводжується виділенням в атмосферу (г/сек.): бензапірену - 616, H2S - 3.7, ціанідів - 4.6, NOx - 20, CO - 317. Забруднення стічних вод супроводжує операції вуглезбагачення i пиловловлювання, хімічних процесів, а також процесів гасіння коксу. Витрати води на 1 т коксу складають приблизно 1,2-1,6 м³. В процесі очищення коксового газу від сірководню миш'яково-содовим методом утворюється 4-6 м³ год стоків, які містять феноли, аміак, сірководень, ціаніди, бензоли, смоли;

- агломераційне є джерелом викидів шкідливих речовин в атмосферне повітря внаслідок здійснення процесів, пов'язаних зі спіканням агломераційної шихти і охолодженням агломерату, у процесі дроблення шихтових матеріалів і агломерату, грохочення, перевантаження та транспортування. Сумарне виділення пилу, до складу якого входять до $26 \% \mathrm{FeO}, 65 \% \mathrm{Fe}_{2} \mathrm{O}_{3}, 3 \% \mathrm{CaO}$ складає більше 11 кг на 1 т агломерату. Загальна витрата води на 1 т агломерату становить 3,5-7,0 м³ (в тому числі, 3-5 м домішками). Склад стічних вод залежить від складу шихти, що надходить на спікання, системи мокрого очищення газів агломераційних машин і випалювальних печей вапняку, схем водопостачання. Стічні води містять хлориди, сульфіди, кальцій, магній, гідрадний луг, залізо, оксиди кальцію, вуглець. Зміст зважених часток в стічних водах агломераційного виробництва коливається в межах 12-20 г/л. У них міститься до 7\% феромагнітних шламів, що представляють собою суміш руди і вапнякової пилу;

- доменне при продукуванні однієї тонни чавуну створює викиди доменного газу в межах 2000-4000 $\mathrm{m}^{3}$, до складу якого входить 3.5-3.6\% водню, 0.1-0.4\% кисню, 0.1-0.6\% метану, 55\% азоту, 25-32\% оксиду вуглецю, 10-15\% діоксину вуглецю, значна кількість пилу. Виплавлення ферромарганцевого чавуну передбачає забруднення стічних вод ціанідами, радоністиним сполуками, аміаком тощо. Охолодження доменної печі передбачає значні обсяги витрат прісної води (до $30 \mathrm{~m}^{3}$ при виплавці 1 т чавуну), а очищення $1000 \mathrm{~m}^{3}$ газу, гідравлічний збір пилу і просипів підбункерного приміщення, грануляція доменного шлаку утворюєть до 4-6 м стічних вод, що містять частки руди, коксу, вапняку, агломерату, хімічні сполуки (сульфати, хлориди), уламки застиглого чавуну, окалини, графіту, недогашенного вапна, а також розчинені гази;

- виробницто феросплавів у відкритих, а також закритих печах, є джерелом викидів газів та пилу, що містять оксиди заліза, міді, цинку, свинцю, хрому, кремнію, ціаніди, фториди, сірчистих та інших шкідливих речовин. Стічні води феросплавного виробництва характеризуються наявністю зважених речовин 3 проявом лужної реакції, вони містять феноли, ціаніди, роданіди, марганець, залізо, хром, миш'як, ванадій;

- виробництво сталі трьома способами: конвертерним - 71\%, мартенівським - 23\%, електросталеплавильним - 6\%. За підсумками 2018 року в країні працювало 20321 доменної печі, 839 мартенівських печей, 15 з 16 конвертерів, 6 з 15 електропечей та всі 15 машин безперервного лиття заготовки. Мартенівський спосіб виплавки сталі є найбільш енерговитратним і екологонебезпечним. Викиди газу від 
діяльності мартенівської печі містять оксид і діоксид вуглецю, оксиди азоту та сірки, кисень, водень, азот, водяну пару та деякі інші речовини. В атмосферне повітря також потрапляє значна кількість пилу ( до 15 г/ м³), який складається переважно з оксидів заліза (близько 88\%), оксидів алюмінію, марганцю та інших речовин, що входять до складу шихти. Крім пилу, у вихідних мартенівських газах містяться шкідливі газоподібні

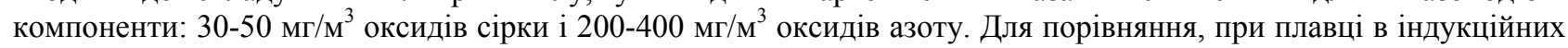
печах утворюються пилу і газів в 5 разів менше. У зв'язку з меншою енергоємністю киснево-конвертерного способу виробництва сталі в порівнянні 3 мартенівським способом, частка виплавки конвертерної сталі безперервно збільшується. На 1 т плавки в конвертері утворюється до $90 \mathrm{~m}^{3}$ газу і до 20 кг пилу. Пил складається, в основному, із заліза і його оксидів (60-70\%), вапна (5-17\%), кремнію (0,7-3,0\%) і деяких інших компонентів. 3 конвертерними газами викидається до 14\% сірки, що міститься в шихті, 3 них 13\% міститься в пилу і $1 \%$ в газовій фазі. У сталеплавильному виробництві стічні води утворюються при очищенні газів мартенівських печей, конвертерів, електропечей, охолодженні і гідроочистки виливниць, установок безперервного розливання сталі і обмивання котлів-утилізаторів. Виробництво 1 т сталевого прокату потребує споживання в межах 180-200 м³ води. Зміст зважених часток в таких стоках досягає 7000 мг/л, до їхнього складу входять феноли, ціаніди, роданіди, марганець, залізо, хром, миш'як, ванадій та ін.

Стає очевидним, що функціонування та подальше економічне зростання металургійних підприємств можливе лише за відмови від техногенного типу економічного розвитку, яке спричиняє швидке і виснажливе використання невідновлюваних видів природних ресурсів, надексплуатація відновлюваних ресурсів (грунти, водні ресурси тощо) зі швидкістю, що перевищує можливості їх відтворення і відбудови.

Більш прийнятною альтернативою стала концепція сталого розвитку (Sustainable development), початок розвитку якої пов'язують з дослідженнями Римського клубу першої половини 70-х років ХХ ст. та розробкою системи ідей і концепцій, яка отримала назву “нового гуманізму”. Стратегію була розроблено у відповідності до чинної Програми ООН з навколишнього середовища (ЮНЕП, 1972). Принципово нові ідеї та принципи сталого розвитку було викладено у праці Д. Медоуз, Й. Рандерс, Д. Медоуза і В. Беренса "Межі зростання", виданої 1972 р. [28]. Основними заходами у процесі формування Концепції сталого розвитку стали: звіт Всесвітньої комісії ООН з навколишнього середовища і розвитку (1987р.), конференція ООН з проблем навколишнього середовища і розвитку в Ріо-де-Жанейро (1992р.), Всесвітній самміт з питань сталого розвитку в Йоганнесбурзі (2002 р.).

Основною ознакою господарства країн ЄС стає екологізація промислового процесу, можливість досягнення економічного росту та одночасного збереження природи, упередження конфліктів між цими сферами буття людей. 3 1990-х років зазаначена концепція є офіційним курсом державної екологічної політики Голландії, Німеччини, Великої Британії [4, с. 329].

У “Проекті стратегії сталого розвитку України на період до 2030 року” [21, с.6] сталий розвиток визначено як нову світоглядну, політичну та практичну модель розвитку для країн світу, які розпочали перехід від суто економічної моделі розвитку до пошуку оптимального балансу між трьома складовими розвитку економічною, соціальною та екологічною.

Визначальне місце у забезпечені сталого розвитку металургійних підприємств належить екологічній складовій, якою передбачається захист його екологічних систем від різного роду екологічних ризиків та забезпечення його екологічної безпеки.

Забезпечення екологічно безпечного та економічно ефективного функціонування та розвитку металургійних підприємств обумовлює необхідність формування нової синергетичної системи, яка здатна до адаптації, самоорганізації та розвитку. ЕЕС є прикладом такої системи, що спрямована на мінімізацію ризиків забруднення навколишнього природного середовища та зменшення економічних збитків суб’єктів господарської діяльності.

Необхідність формування ЕЕС металургійних підприємтв обумовлена наступними причинами:

- зменшення негативного впливу виснажливого використання невідновлюваних видів природних ресурсів та надексплуатації відновлюваних ресурсів у стратегічній перспективі;

- покращення екологічної ситуації у регіонах за рахунок зменшення техногенного навантаження на навколишнє середовище в міських агломераціях;

- підвищення інвестиційної привабливості територій за рахунок додаткових можливостей капіталовкладень в екологічні проекти;

- збільшення вагомості екологічних чинників у забезпеченні конкурентоспроможності металургійних підприємств;

- посилення економічних та адміністративних санкцій за порушення вимог законодавства в галузі охорони навколишнього середовища;

- значне перевищенням економічних втрат металургійних підприємств та регіонів, в яких вони функціонують, внаслідок забруднення навколишнього середовища у порівнянні з їхньою мінімізацією.

Категорію ЕЕС уведено до наукового обігу паралельно із формуванням концепції сталого розвитку у 70-х роках XX ст. разом із близькими за змістом поняттями біоекономічної системи, природно-економічної системаи, соціально-еколого-економічної системи [9]. Наповнення категорії еколого-економічної системи новим змістом отримало продовження в дослідженнях учених економістів України (табл. 1). 
Таблиця 1.

Основні підходи до визначення поняття "еколого-економічна система"

\begin{tabular}{|c|c|}
\hline $\begin{array}{l}\text { О. Каленська } \\
{[7, \text { с. } 84]}\end{array}$ & $\begin{array}{l}\text { обмежене певною територією взаємозалежне функціонування екологічної й } \\
\text { економічної систем, що утворюють цілісну систему з емерджентними властивостями, } \\
\text { елементи якої зв'язані матеріально-фінансово-енергетичними потоками }\end{array}$ \\
\hline $\begin{array}{l}\text { Н. Мойсеєв } \\
{[14, \text { с. } 179]}\end{array}$ & $\begin{array}{l}\text { обмежена певною територією частина ноосфери, в якій природні, соціальні та } \\
\text { виробничі структури і процеси взаємозв’язані взаємодіючими потоками речовини, } \\
\text { енергії та інформації }\end{array}$ \\
\hline $\begin{array}{l}\text { I. Грабинсь } \\
{[4, \text { с. } 328]}\end{array}$ & $\begin{array}{l}\text { утворення, що використовує природні ресурси, ресурси навколишнього середовища, } \\
\text { працю та капітал }\end{array}$ \\
\hline $\begin{array}{l}\text { В. Кислий } \\
{[8, \text { с. } 46]}\end{array}$ & $\begin{array}{l}\text { утворення, що забезпечує використання природних ресурсів, праці, капіталу в } \\
\text { економічних процесах }\end{array}$ \\
\hline $\begin{array}{l}\text { Р. Розум, } \\
\text { Буряк, } \\
\text { Любезна } \\
{[23, \text { с. } 36]}\end{array}$ & $\begin{array}{l}\text { екологоконструктивна діяльність суб'єктів господарювання, що забезпечує } \\
\text { спрямованість і рівень соціально-економічного розвитку суспільства та сприяє якості } \\
\begin{array}{l}\text { внутрішніх еволюційних перетворень у процесі безперервних } \\
\text { економічній рівновазі }\end{array}\end{array}$ \\
\hline $\begin{array}{l}\text { I. Дегтярьова, О. } \\
\text { Мельник, А. } \\
\text { Бондар } \\
{[5, \text { с. } 34]}\end{array}$ & $\begin{array}{l}\text { складне динамічне утворення, що перебуває у стані внутрішньої рівноваги лише за } \\
\text { умови підтримання балансу між асиміляційним потенціалом природного середовища та } \\
\text { антропогенним навантаженням, яке не виходить за рамки асиміляційного потенціалу }\end{array}$ \\
\hline $\begin{array}{l}\text { М. Лемешев } \\
{[10, \text { с. } 268]}\end{array}$ & $\begin{array}{l}\text { інтеграція економіки і природи, що являє собою взаємопов'язане і взаємообумовлене } \\
\text { функціонування суспільного виробництва і проходження природних процесів у } \\
\text { навколишньому середовищі, зокрема, у біосфері }\end{array}$ \\
\hline $\begin{array}{l}\text { Н. Каменева } \\
\text { О. Фещенко } \\
{[26, \text { с. } 224]}\end{array}$ & а, яке поєднує екологічні й економічні інтереси як природних, так і промислових \\
\hline Л. Загвойська & $\begin{array}{l}\text { органічна і динамічна єдність екологічної та економічної систем, які пов’язані } 3 \\
\text { обміном речовини, енергії та інформації, для яких є характерною сильна нелінійна } \\
\text { взаємодія та колективна (виникаюча, емерджентна) поведінка }\end{array}$ \\
\hline $\begin{array}{l}\text { О. Кузьменко } \\
{[9, \text { с. } 220]}\end{array}$ & $\begin{array}{l}\text { еколого-економічна система як змінність ресурсної цінності з екстраполяцією основних } \\
\text { показників економічного зростання й структурних екологічних зрушень }\end{array}$ \\
\hline $\begin{array}{l}\text { Н. Мешеніна, } \\
\text { Мареха } \\
{[13, \text { с. } 147]}\end{array}$ & $\begin{array}{l}\text { сукупність об’єктів природокористування, які залучено до процесів суспільного } \\
\text { відтворення за участю людського фактора, об’єднано метою багатоцільового } \\
\text { використання продуктивних сил суспільства }\end{array}$ \\
\hline $\begin{array}{l}\text { Ю. Бурих, } \\
\text { С. Марова } \\
\text { [2] }\end{array}$ & $\begin{array}{l}\text { сукупність взаємозв’язків між природними, виробничими та соціальними структурними } \\
\text { складовими, що функціонують на єдиній території, відображають вплив економічної } \\
\text { підсистеми на екологію та показники розвитку соціальної підсистеми }\end{array}$ \\
\hline
\end{tabular}

Узагальнення наукових досліджень сутності еколого-економічної системи дає змогу виокремити декілька відмінних підходів: просторово-функціональний $[7,14]$, ресурсний $[4,8]$, системно-синергетичний [5, $6,10,23,26]$, комплексний [2, 13], структурно-динамічний [9].

Для забезпечення ефективності функціонування ЕЕС металургійних підприємств у відповідності до політики охорони навколишнього середовища та стандартів серії ISO 14000, які орієнтовано на поліпшення екологічних характеристик діяльності суб’єктів господарювання, основними напрямами екологічного управління з метою підвищення екологічної дієвості, $є$ :

- формування ЕЕС та системи екологічного менеджменту;

- сертифікація систем екологічного менеджменту на відповідність міжнародним стандартам;

- оцінка впливу на навколишнє середовище та екологічних ризиків;

- ефективне управління екологічними ризиками;

- запровадження систем екологічного моніторингу;

- розробка процедур, що забезпечують попередження i виправлення будь-яких потенційних невідповідностей в рамках ЕEC;

- періодичне проведення екологічного аудиту;

- розробка та реалізація річних і довгострокових екологічних програм.

Екологічні ризики можуть привести до втрати ресурсів, зниження економічної ефективності металургійних підприємств, що в свою чергу, призводить до зниження обсягів збуту і здатності платити за зобов'язаннями підприємства (перші ознаки нестабільності господарсько-економічної діяльності підприємства). Внаслідок цього стають нові ризики виникнення збитків для зовнішнього соціально-економічного середовища, а також навколишнього середовища. Це призводить до необхідності використовувати систему управління екологічними ризиками в загальній еколого-економічної системі металургійного підприємства. Пріоритетним є вивчення та оцінювання екологічних ризиків, визначення їхньої економічної вартості, обгрунтування 
екологічних заходів з управління еколого-економічною діяльністю підприємства та зіставлення економічних результатів упровадження природоохоронних заходів з витратами здійснення, що дозволяє прогнозувати розвиток за умов невизначеності.

Виходячи з цього, а також приймаючи до уваги цілі та завдання EEC, на рис. 2 представлено схему економічного оцінювання екологічних ризиків підприємств металургійної промисловості.

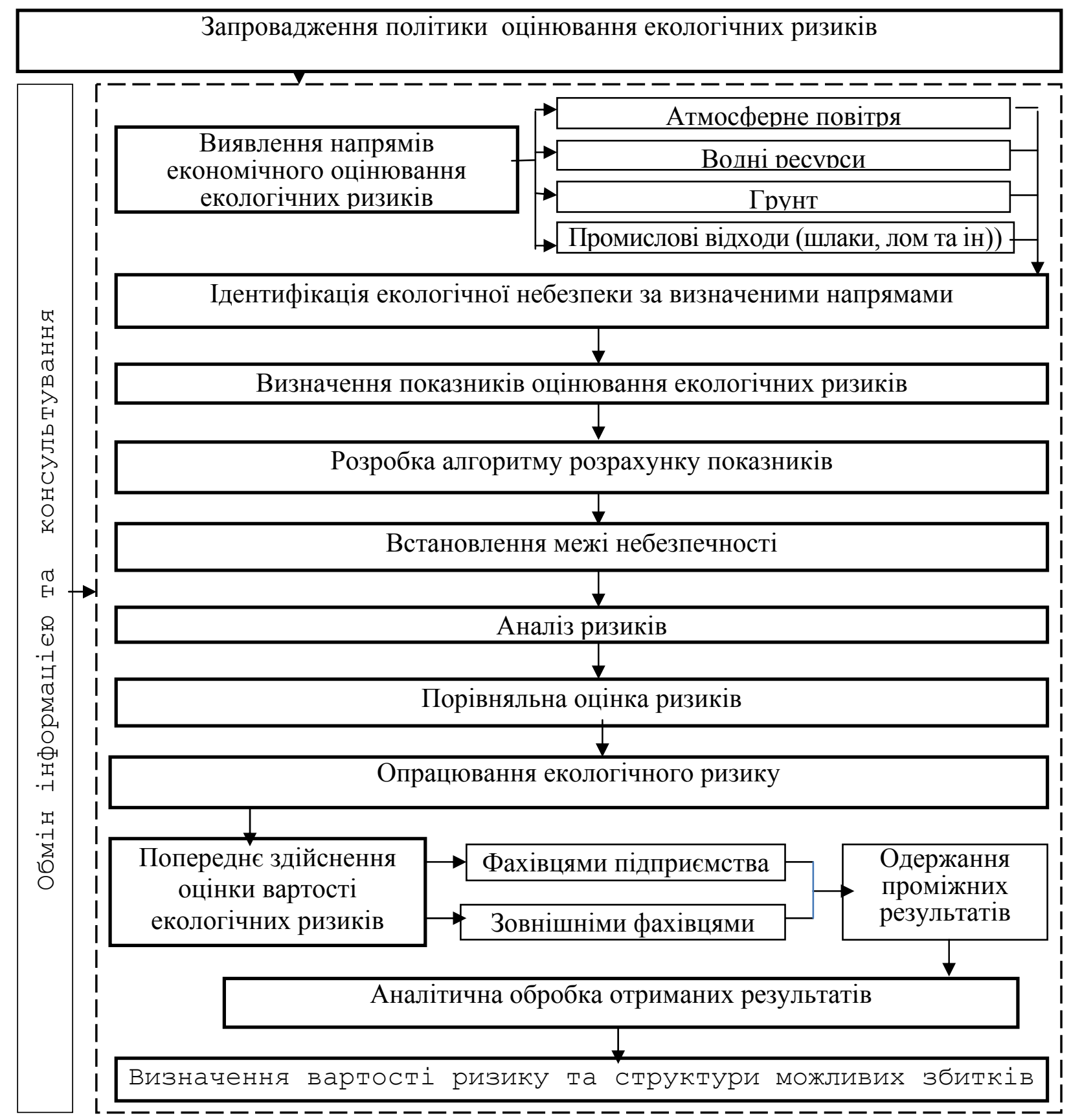

Рис. 2. Схема процесів економічного оцінювання екологічних ризиків діяльності металургійного підприсмства

Джерело: розробка автора

До процесу економічної оцінки екологічного ризику належить визначення вартості та структури можливих збитків, які пов'язано із забрудненням повітря, води, поверхні та надр. В Україні затверджено Методики розрахунку розмірів відшкодування збитків, які заподіяні державі в результаті наднормативних викидів, що забруднюють атмосферне повітря, водні басейни, земельні ресурси $[11 ; 12 ; 17]$. Методики розроблено у відповідності до законів України "Про охорону навколишнього природного середовища" (1264-12) [20] та “Про охорону атмосферного повітря” (2707-12) [19], постанов Кабінету Міністрів України від 17.11.2001 р. №1520 (1520-2001-п) “Про затвердження Положення про Державну екологічну інспекцію України”, № 454/2011 від 13 квітня 2011 р. [16] “Про затвердження нормативів граничнодопустимих викидів забруднюючих речовин із стаціонарних джерел”, що зареєстровано в Міністерстві юстиції України від 27 червня 2006 р. № 309 [18]. 
Використання у діяльності металургійних підприємств ефективних методів управління екологічними ризиками є визначальним для сталого розвитку у статегічній перспективі самих підприємств, металургійного комплексу України та української економіки в цілому. Особливості управління екологічними ризиками металургійних підприємств обумовлені масштабами виробництва, особливостями виробничих процесів та значним впливом на зміну стану довкілля на територіях функціонування самих підприємств.

Обов'язковою умовою управління екологічним ризиком є його інтеграція до загальної системи управління підприємства. Зазвичай, металургійні компанії включають до своїх корпоративних стратегій розділи, які пов'язані із забезпеченням ефективного управління екологічними ризиками. Враховуючи досвід побудови систем управління різними видами ризиків, нами запропоновано принципову схему процесів управління екологічним ризиком металургійних підприємств як окремого специфічного об'єкту управління (рис. 3).

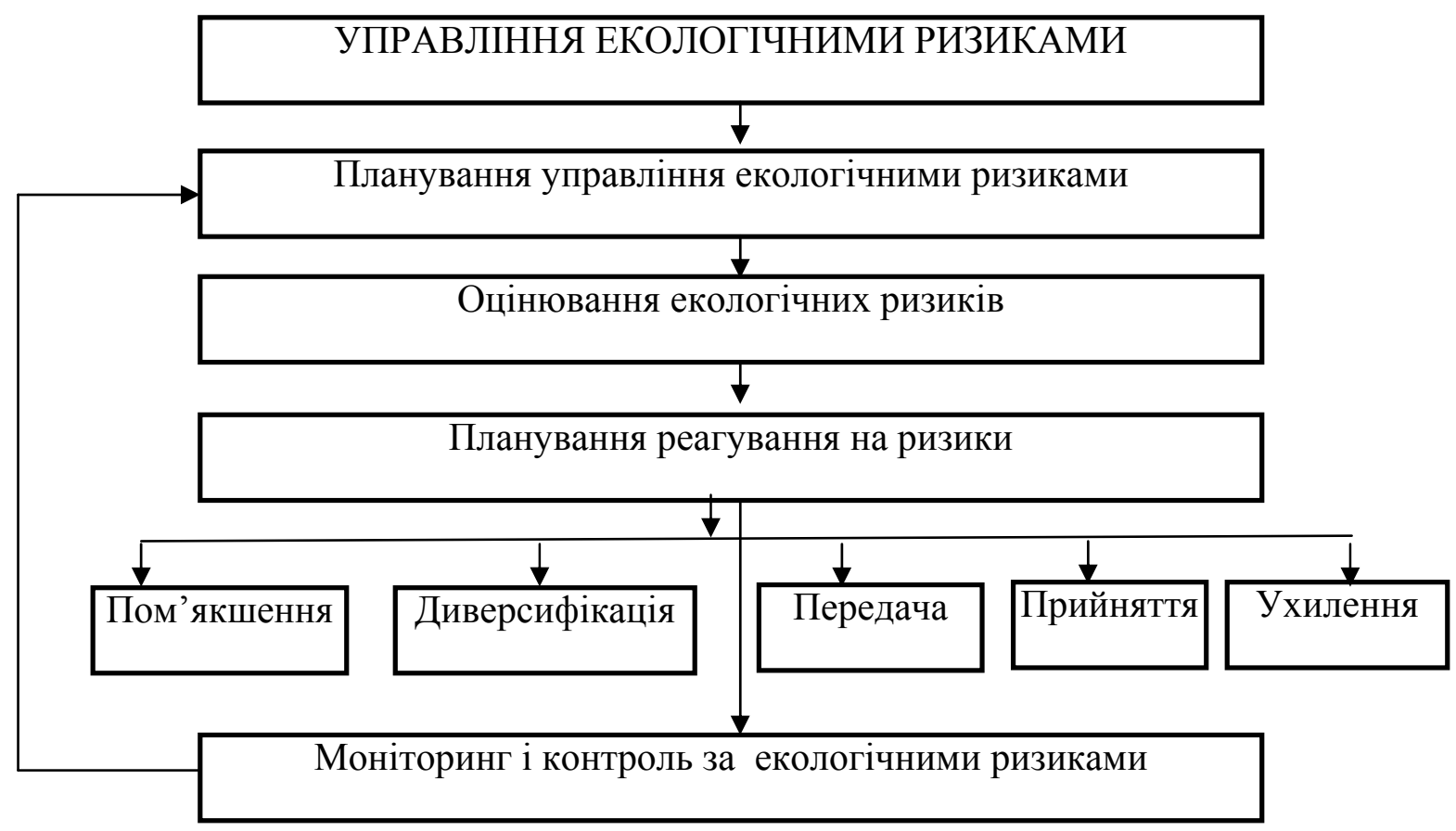

Рис. 3. Схема процесів управління екологічними ризиками Джерело: узагальнено автором

Планування процесами управління екологічними ризиками покликане забезпечити підвищення ймовірності успішного досягнення результатів всього процесу управління ризиками та передбачає прийняття рішень щодо вибору принципового підходу, планування та здійснення заходів управління екологічними ризиками.

Планування заходів реагування на ризики передбачає розроблення альтернативних стратегій реагування на ризики, які спрямовано на підвищення сприятливих можливостей і зниження несприятливого вливу екологічних ризиків [22]. Процес включає проектування можливих та вибір оптимальних стратегії, а також планування дій щодо їхньої реалізації. Результатами планування реагування на ризики, зазвичай, $є$ карти ризиків, що включають також дії реагування на ризики.

Здійснення моніторингу і контролю за екологічними ризикама передбачає відстеження ідентифікованих ризиків, моніторинг залишкових та ідентифікацію нових ризиків, виконання планів реагування на ризики i оцінювання їхньої ефективності протягом життєвого циклу проекту [27].

Метою моніторингу і контролю є з'ясування наступних аспектів управління екологічними ризиками:

- відповідність впровадження (комплаєнс-контроль) системи реагування на ризики;

- рівень реагування на ризики;

- зміни ризиків у порівнянні з попередніми значеннями;

- ефективності заходів з реагування на ризики;

- рівень впливу заходів на екологічні ризики;

- аналіз резервів.

Результатом цього процесу мають стати перероблені та оновлені плани реагування на ризики, корегувальні дії, вимоги до змін, стандартні звіти з управління екологічними ризиками. Контроль сприяє вибору альтернативних стратегій, ухваленню корективів, переплануванню проекту 3 метою забезпечення базового плану.

Висновки. Проведене дослідження впливу виробничої діяльності металургійних підприємств на забруднення навколишнього середовища, аналіз процесів оцінювання та управління екологічними ризиками, даєють чітке розуміння того, що ЕЕС сприяє розв'язанню низки екологічних та економічних проблем, сталому 
розвитку металургійних підприємств, регіону розташування та української економіки в цілому. Для формування ефективної ЕЕС металургійної промисловості має бути розроблено та запроваджено дієвий алгоритм заходів, які спрямовано на визначення, оцінювання та управління екологічними ризиками із застосуванням оновлених інноваційних методів. У перспективі передбачається дослідження практичного досвіду впровадження ЕЕС на вітчизняних підприємствах металургійної промисловості з метою визначення їхньої екологічної, економічної і соціальної доцільності та ефективності.

\section{Список використаних джерел.}

1. Білецька Е. М. Онул Н. М., Ніконенко В. І. Металургійні підприємства як джерело забруднення атмосферного повітря та фактор ризику погіршення здоров'я населення. медичні перспективи. Медичні перспективи. 2018. Т. 23, № 3(1). С. 17-22.

2. Бурих Ю.В., Марова С.Ф. Методичні підходи до визначення поняття «еколого-економічна система»: 3б. наук. пращь Донецького держуніверситету управління. Сер. Держуправління. 2014. Т. 15. Вип. 291. С. 34-42.

3. Главинская Л.Т. Экологический менеджмент и устойчивое рачвитие. Вестник Московского университета. Сер. 6. Экономика. 2005. № 2. С. 28-34.

4. Грабинський I.М., Федунь Ю.Б. Реалізація політики сталого еколого-економічного розвитку в країнах ЕС: досвід для України. Менеджмент та підприємництво в Україні: етапи становлення $і$ проблеми розвитку. Вісник Національного університету «Львівська політехніка». 2010. № 691. С. 327-333.

5. Дегтярова І.Б., Мельник О.І., Бондар А.В. Синергетичні ефекти еколого-економічних систем в умовах інформаційної економіки. Механізм регулювання економіки. 2013. № 3. С. 30-37.

6. Загвойська Л.Д., Пелюх О.Р. Епістемологічний інструментарій дослідження еколого-економічних систем. Наукові праці Лісівничої академії наук України. 2019. № 18. С. 154- 163.

7. Каленська О.О. Еколого-економічна система регіону: визначення, структура, взаємодії. Вісник СумДУ. Сер. Економіка. 2010. № 1. С.83-84.

8. Кислый В.Н. К вопросу о сущности понятия «эколого-экономический ущерб». Вісник СумДУ. Сер. Економіка. 2007. № 1. Т. 2. С. 43-50.

9. Кузьменко О.К. Еколого-економічна система: поняття та структура. Вісник Полтавськоі державної аграрної академії. 2012. № 2. С. 217-221.

10. Лемешев М.Я. Эколого-экономическая модель природопользования. Всесторонний анализ окружающей природной среды. Л.: Гидрометеоиздат, 1976. С. 266-276.

11. Методика визначення розмірів шкоди, зумовленої забрудненням і засміченням земельних ресурсів через порушення природоохоронного законодавства: наказ Міністерства охорони навкол. природ, середовища та ядерної безпеки України від 27 жовт. 1997 р. № 171. Офімійний вісник Украӥни. 1998. № 18.С. 664.

12. Методика розрахунку розмірів відшкодування збитків, які заподіяні державі в результаті наднормативних викидів забруднюючих речовин в атмосферне повітря: наказ Міністерства охорони навкол. природи, середовища України від 10 груд. 2008 р. № 639. Офіиійний вісник Украӥни. 2009 №5. С. 151.

13. Мешеніна Н.В., Мареха I.С. Аналіз підходів до визначення еколого-економічних систем. Сталий розвиток та екологічна безпека суспільства в економічних трансформаціях: матеріали Другої наук.-практ. конф., 23-24 вересня 2010 р. Сімферополь: Фенікс, 2010. С.147-148.

14. Моисеев Н.Н. Наука, глобальные модели и перспективы человечества. Горизонты экологического знания. К.: Наука, 1986. С. 179-200.

15. Огляд стану забруднення навколишнього природного середовища на території України у 2018 році. URL: http://www.cgo.kiev.ua/index.php?fn=u_zabrud\&f=ukraine\&p=1 (дата звернення: 25.11.2019).

16. Положення про Державну екологічну інспекцію України: Указ Президента України № 454 / 2011 від 13 квіт. 2011 р. Офіиійний вісник Украӥни. 2011. № 29. С. 1260.

17. Про затвердження змін до Методики розрахунку розмірів відшкодування збитків, заподіяних державі внаслідок порушення законодавства про охорону та раціональне використання водних ресурсів: наказ М-ва екології та природ, ресурсів України від 30 черв. 2011 р. № 220. Офіиійний вісник України. 2011 . № 58. Ст. 2331.

18. Про затвердження нормативів граничнодопустимих викидів забруднюючих речовин із стаціонарних джерел: наказ М-ва охорони навкол. природи, середовища України від 27 черв. 2006 р. № 309. Офічійний вісник Украӥни. 2006. №31. Ст. 2259.

19. Про охорону атмосферного повітря: Закон України від 16 жовт. 1992 р. № 2707-ХII: за станом на 14 лип. 2016 р. Відомості Верховної Ради Украӥни. 1992. № 50. С. 678.

20. Про охорону навколишнього природного середовища: Закон України від 25.06.1991 р. № 1264-XII. URL: https://zakon.rada.gov.ua/laws/ show/1264-12 (дата звернення: 04.12.2019).

21. Проект Стратегії сталого розвитку України на період до 2030 року URL: http://www.ua.undp.org/content/dam/ukraine/docs/SD\%20Project_Ukraine_version\%203-2-1.pdf?download____дата звернення 29.11.2019).

22. Американский национальный стандарт. Руководство к своду знаний по управлению проектами (Руководство РМВОК)/РMI. 5-еизд. Project Management Institute, Inc., 2013. 587c. 
23. Розум P.І., Буряк М.В., Любезна I.В. Еколого-економічні системи: основні аспекти. Науковий огляд. Київ. 2015. № 6 (16). С. 33-49.

24. Стародубцев И.А, Елохин А.П. К вопросу об использовании автоматизированных систем контроля экологической обстановки на территориях, прилегающих к предприятиям черной, цветной металлургической и атомной промышленности. глобальная ядерная безопасность, 2015 №4(17), С. 15-34.

25. Татаркин А.И, Куклин А.А., Черепанова А.В. Социально-демографическая безопасность регионов России: текущее состояние и проблемы диагностики. Экономика региона. 2008. № 3 (15). С. 153-161.

26. Фещенко О.Л., Каменева Н.В. Оцінка впливу діяльності металургійних підприємств на навколишнє природне середовище України. Інвестиції: практика та досвід. 2016. № 2. С. 28-32.

27. Фещенко О.Л., Каменева Н.В. Теоретичні засади визначення поняття еколого-економічної безпеки підприємства. Університетські наукові записки. 2017. № 1. С. 223-231.

28. Meadows, D.H., Meadows, D.L., Randers, J., Behrens W.W. III. The Limits to Growth: A Report to The Club of Rome on the Predicament of Mankind. New York: Universe Books, 1972. 205 p.

\section{References.}

1. Biletska, E.M., Onul, N.M. and Nikonenko, V.I (2018), "Metallurgical enterprises as a source of atmospheric air pollution and a risk factor for deteriorating population health", Medychni perspektyvy, vol. 23, 3(1), pp. 17-22. Ukraine.

2. Burykh, Ju.V. and Marova, S.F. (2014), "Methodical approaches to defining the concept of "ecological and economic system", Zb. nauk. pracj Donecjkogho derzhuniversytetu upravlinnja. Ser. Derzhupravlinnja, T. 15, Vyp. 291, pp. 34-42. Ukraine.

3. Glavinskaja, L.T. (2005), "Environmental Management and Sustainability", Vestnik Moskovskogo universiteta, Serija 6: Ekonomika, vol. 7, pp. 28-34. Russia

4. Hrabynskyi, I.M. and Fedun, Yu.B. (2010), "The policy implementation of sustainable environmentaleconomic development in Eu countries: experience for Ukraine", Menedzhment ta pidpryiemnytstvo v Ukraini: etapy stanovlennia i problemy rozvytku, Visnyk Natsionalnoho universytetu «Lvivska politekhnika», vol. 691, pp. 327-333. Ukraine.

5. Deghtjarova, I.B., Meljnyk, O.I. and Bondar, A.V. (2013), "Synergetic effects of ecological and economic systems in information economy", Mekhanizm reghuljuvannja ekonomiky, vol. 3, pp. 30-37. Ukraine.

6. Zahvoyska, L. and Pelyukh O. (2019), "Epistemological instruments for ecological-economic systems investigation”. Naukovi pratsi Lisivnychoi akademii nauk Ukrainy, vol. 18, pp. 154-163. Ukraine.

7. Kalens'ka, O.O. (2010), "Ecological and economic system of the region: definition, structure, interaction".Visnyk SumDU, Ser. "Ekonomika", vol.1, pp.83-84. Ukraine.

8. Kyslyj, V.N. (2007), "On the essence of Eco-economic detriment", Visnyk SumDU, Ser."Ekonomika", vol.1, vol. 2, pp. 43-50. Ukraine.

9. Kuzjmenko, O.K. (2012), "Ecological and economic system: concept and structure". Visnyk Poltavsjkoji derzhavnoji aghrarnoji akademiji, vol. 2, pp. 217-221. Ukraine.

10. Lemeshev, M.Ya. (1976), "Ecoeconomic model of natural resources", Lviv, Vyd-vo Hydro- meteoyzdat, pp. 266-276. Ukraine.

11. Ministry of Environmental Protection and Nuclear Safety of Ukraine (1998), The order "Methodology for determining the amount of damage caused by pollution and contamination of land resources due to violation of environmental legislation". Ofitsiinyi visnyk Ukrainy, vol. 18, p. 664.

12. Ministry of Environmental Protection of Ukraine (2008), The order "Methodology for determining the amount of compensation for losses caused to the state as a result of excess emissions of pollutants into the air" Ofitsiinyi visnyk Ukrainy, vol.5, p. 151.

13. Meshenina N.V. and Marekha I.S. (2012), "Essential categories and factors of using labor resources potential of the population", Stalyi rozvytok ta ekolohichna bezpeka suspilstva v ekonomichnykh transformatsiiak [Sustainable development and environmental security of society in economic transformation], Materialy druhoi Vseukrainskoi naukovo-praktychnoi konferentsii [Conference Proceedings of the Second All-Ukrainian Scientific and Practical], Simferopol: Fieniks, Ukraine, of September 23-24, pp. 147-148.

14. Moyseev, N.N. (1986), "Science, global models and prospects of humanity", Horyzonty ekolohycheskoho znanyia, Kyiv, pp.179-200. Ukraine.

15. Overview of the state of environmental pollution in Ukraine in 2018, available at: URL: http://www.cgo.kiev.ua/index.php? $f n=u \_z a b r u d \& f=u k r a i n e \& p=1$ (Accessed 25 November 2019).

16. The President of Ukraine (2011), "Regulation on the State Environmental Inspection of Ukraine " Ofitsiinyi visnyk Ukrainy, vol. 29, p. 1260.

17. Ministry of ecology and natural resources of Ukraine (2011), The order "On Approving Changes to the Methodology for Calculating the Amounts of Damage Damage Caused by the State as a result of Violation of the Law on Protection and Rational Use of Water Resources " Ofitsiinyi visnyk Ukrainy, vol.58. p. 2331.

18. Ministry of ecology and natural resources of Ukraine (2006), The order "On approval of emission limit values for pollutants from stationary sources", Ofitsiinyi visnyk Ukrainy, vol.31, p. 2259.

19. The Verkhovna Rada of Ukraine (1992), The Law of Ukraine "On the protection of atmospheric air ", Vidomosti Verkhovnoi Rady Ukrainy, vol. 50, p. 678. 
20. The Verkhovna Rada of Ukraine (1991), The Law of Ukraine "On the protection of the environment", available at: https://zakon.rada.gov.ua/laws/ show/1264-12 (Accessed 4 December 2019).

21. UNU (2016), Project "Sustainable Development Strategy for Ukraine by 2030". Available at: http://www.ua.undp.org/content/dam/ ukraine/docs/SD\%20Project_Ukraine_version\%203-2-1.pdf?download (Accessed 5 December 2019).

22. PMI (2012), "American National Standard "Guide to the Body of Knowledge Project Management (Guide PMBOK)", 5rd ed., PMI, Newtown Square. USA.

23. Rozum R.I., Buriak, M.V. and Liubezna, I.V. (2015), "Ecological-economic systems: the main aspects", Naukovyy ohlyad. Kyiv. vol. 6 (16). pp.33-49. Ukraine.

24. Starodubcev, I.A. and Elokhin, A.P. (2015), "Use of Automated Systems for Environmental Monitoring in the Area Surrounding Ferrous, Nonferrous Metallurgical Enterprises and Nuclear Industry", Globalnaja yadernaja bezopasnost, vol. 4(17), pp. 15-34. Russia.

25. Tatarkin, A.I., Kuklin, A.A. and Cherepanova, A.V. (2008), "Socio-demographic safety of regions of Russia: current condition and problems of diagnostics". Ekonomika regiona, vol. 3, pp.154-162. Russia.

26. Feshhenko, O. and Kameneva, N. (2016), "Assessment of the impact of the activities of metallurgical enterprises on the environment in Ukraine", Investytsiyi: praktyka ta dosvid, vol. 2, pp. 28-32. Ukraine.

27. Feshchenko, O.L. and Kameneva, N.V. (2017), "Theoretical Basis of the Definition of the Notion of the Enterprise's Ecological and Economic Safety", Universytetski naukovi zapysky. vol. 1, pp. 223-231. Ukraine.

28. Meadows, D.H., Meadows, D.L., Randers, J. and Behrens W.W. III. The Limits to Growth: A Report to The Club of Rome on the Predicament of Mankind (1972), New York: Universe Books, 205 p. USA.

Стаття надійшла до редакиії 20.01.2020 p. 